\title{
AMERICAN JUSTICE--a new OXYMORON
}

This issue is 15 Whitmanesque articles of what Dr. Nigro experienced and witnessed and documents the need for truth and justice in American law and for major reform of prison rehabilitation and correction efforts.

Justice is contradicted when one's government over criminalizes and over-incarcerates as part of its regimented Soviet-like over-control and plunder of allegedly freeborn citizens. The government is filled with malicious vigilantes masquerading as promoters of the common good when, in reality, they only promote what valueless virtue-less liberal looney editors have managed to manipulate the people into behaving like Pavlovian dogs converting their own minds into the un-Natural. Basically, excepting most in the military, the emotion of being in government law is a grandiose abuse of the great American propaganda of life, liberty and the pursuit of happiness for all. As a Great Course on evil once stated that government "law does not care about truth or justice but legalisms." Thus, "American Justice" is an oxymoron.

In Cleveland, Ohio, and elsewhere, sweeping reforms are now in process to help police deal with people by sensitivity training, "de-escalation of conflict," "cultural competency," "biasfree policing," new rules for lies, less violence and more tracking performance. However, what police groups need, pales in contrast to reforms needed by the entire legal, law, and government systems--now a totalitarian system (an insult to the Founders) which has incarcerated for over two decades each more than 300 innocent men (and magnitudes are still unfree because there is no DNA proof of innocence of who knows how many others). This is at least 6000 years of accumulated unjust imprisonment for these innocent 300 men--proof of the need for sweeping reforms to reacquire Founders' virtue, truth and justice (and reforms must include that no one is allowed to hold any government office without having serving three years honorably in the military). The opinions and poems in this issue are to awaken from the American Nightmare of fast-food-like legalisms which have made "American Justice" into an oxymoron:

1. Machiavelli was correct when he stated that those in government will destroy those who criticize. I discovered that those in government are very sensitive, seeing all criticism as threat to their power. I also discovered that government workers consider "improvement suggestions" as "criticisms" also, because "better ways of doing things" means inadequate performance for the job they are doing. I found government workers must present themselves as "infallible" (not needing help or criticism) to protect themselves and all above them in the government hierarchy. This "infallibility" is a singspiele truism which cannot be denied by American traitors in government functioning causing disappearance of truth and justice. To the contrary, all government workers must learn to accept all criticism and offers to help in good faith without paranoia.

2. All government workers, from the White House to Medicare paper clerk, function based on power, which means power must be used or one loses identity, credibility and self-worth. This was proven by the

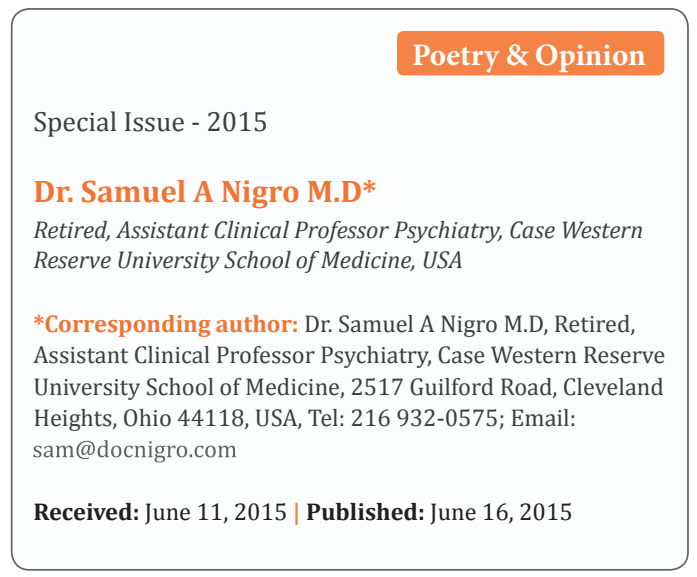

Stanford Penitentiary Experiment (check on the Web) which demonstrated the automatic corrupting effects of power even on bright idealistic college students. Power creates a cesspool of government hunter-hater-killers of citizens turning them into "subjects" of the arrogant royalty in charge. All government workers should take an oath with the President at every State of the Union Address swearing not to follow the Stanford Penitentiary Experiment findings.

3. All government workers compose a unity of authoritarianism which Franz Jagerstatter called "a gang" because the workers dutifully followed peers, in obedience to orders or influences from above, to do what was unjust if not evil. Stanley Milgrim Suggestibility (check on the Web) proves the interdependence and compliance to "gang-like" behavior. Basically, suggestible manipulated Americans love to be idiots for the latest flimflam for personal aggrandizement masquerading as public good. All government workers should take an oath with the President at every State of the Union Address swearing not to follow the Stanley Milgrim Suggestibility findings.

4. "Equality before the law" is a myth especially by "Ignorance of the law is no excuse." There are law libraries filled with laws. The common man cannot know them all and new laws metastasize daily from the scribes, Pharisees, and Herodians in government. The law is a self-inflated confidence game based on P.T. Barnum as law school dean. No one should be prosecuted without a one year notification of the law and corrective intervention offered concerning the laws allegedly being violated. And no proceedings can continue without a fair, truth-seeking Grand Jury processing which is now little more than absurd rubber-stamping of whatever the prosecution presents. 
5. Prosecutors, investigators, judges, and witnesses must all take an oath for all matters to "tell the truth, the whole truth, and nothing but the truth". Without that, "equality before the law" is a myth. Truth and justice pretended, the law is a bunch of legalism cue cards (used as in a pretentious Scrabble-Game-like selection process) to oppress citizens and to give the tabloid press and media sensational themes supporting the politicians involved. Truth is relevant only if ALL take the oath for truth. All investigators must wear audio cameras documenting fully ALL their investigative activities. No investigation findings can be used when gathered and processed without complete audio camera verification.

6. The Constitution guarantees a jury trial, but plea bargains slickly deprive of a jury trial in $90 \%$ of criminal cases, which an outrageous defecation on the U.S. Constitution. This is because the accused is routinely over welmed by calculated, arbitrary and capricious schemes of multiple counts, the number of which forces acceptance of plea bargained lesser charges (often a "plea perjury" rather than "bargain"). Judicial imagination macerates to see what is not there. This can be remedied by "each initial charge count is a juror" equivalent. That is, all initial charges/counts must be proven for a "guilty" ruling. Thus "Innocent until proven guilty" means more than accepting a spurious plea of guilt--It means "Innocent until proven guilty by a constitutionally guaranteed jury of one's peers." Corrective actions include prohibiting "counts" being bargained away. If a count is filed, it must be proven...If 50 counts are filed, all 50 counts must be proved for a "jury equivalent" ruling of "guilt." And plea bargains cannot be construed to mean "proven guilt." Until guilt is "proven", one remains factually innocent even if administratively (plea bargained--which is not "proven") "guilty".

7. As medical records have been opened to ensure justice, so must all legal records be opened in court proceedings so that truth and justice prevail. "Justice" is a joke with closed legal records. Like medical records now, legal records must contain precisely defined procedures and services which are coded and fee-set as are medical records. Without open records, the law is a vaudeville stage. The law is an unprofessional capitalist business sham until all records are open as in medicine.

8. If "equality before the law" is a norm, financial considerations must be equalized. Those in the law leak money and dishonor at every pore. There is no "equality" without "cost" equality.

9. Investigators, especially, must be equalized by a "counter-investigator" by Inspector General's Office (although IG people are part of the "gang" too and thus may be suspect?) for all alleged breaking of any law. Investigators are really glib "salesmen" notorious for egoism, Narcissism, false accusations, maliciousness, slander, defamation, prevarications, suppression of any exculpatory evidence, witness coaching, false evidence creation, blatant retaliation, and pervasive arbitrary and capricious proclamations to manipulate the press and hypnotize the overly suggestible, self-deluded arrogant judge even when there was a "plea bargain" not to do so. All in the law are show-biz John Wayne wannabes. The oath for "truth" should help.

10. "Innocent until proven guilty" ("presumption of innocence") is fantastic humbug and no longer a good faith component of government law especially apparent in prosecution and government actions. Non-judicial judges, especially if female, are especially prone to the magnificent lie fests from tawdry investigators skilled in dogmatic flimflam. Judges are not "equal" but are prima donnas gloating over their hagiography as continuously proclaimed from the first day of law school. Prosecutors and investigators, above all, are salesmen for their conviction rates. A judge's required oath for truth should help even if she is self-infatuated (as all judges are as required by the self-inflated image the law imposes for itself) and non-judicially ignorant of objectivity (as most are led to non-being by the lies of the prosecution and investigators).

11. Dealing with the press is totally unequal before the law. Even with plea bargains, the prosecution will give mountains of baloney to the press while the defendants are prohibited response or factual clarifications by their attorneys because of automatic vicious retaliation by the prosecutor (who as a politician does not want any negative publicity). Public notices to the press should be prohibited consideration in any judicial proceedings--jurors are regularly instructed to ignore non-court information--and so should the judge. The entire court should also be so required. But free speech must be equally allowed to the free press without negative consequences.

12. The financial gains by those in government are outrageous. To help with the current government debt, ninety percent of all assets accumulated while in office and since, by all ever in government (and their families) of the last 50 years should be confiscated. The 45 million dollar worth of the Clintons comes to mind. The national debt will be helped greatly by recovery of what politicians have extorted from citizens by special privileges and benefits not available to the common citizen. Until this happens, our politicians in office have become "royalty" in the worst senses of the word.

These proposals are gifts to citizens deserving to live free with a government filled with overlords, tyrants, and emperors worse than King George III. The legal system is an untrustworthy opportunistic capitalist business--a prison industry run by politicians with fabricated reputations using press \& media standards. It is time for a new revolution. To begin with, more than sixty (60!) centuries of imprisoned innocents are enough, and more is needed than "consent decrees" for police organizations. Until these steps happen, American Justice is an oxymoron. 